\title{
Information Technology Solutions for Management of Analytical Methods
}

\author{
Luciano de Sousa Moraes \\ Tocantins Institute of Science and \\ Technology, \\ Colinas do Tocantins/Tocantins - \\ Brazil
}

\author{
Glêndara Aparecida de Souza \\ Martins \\ Food Engineering Department \\ University Federal of Tocantins \\ Palmas/Tocantins - Brazil
}

\author{
Warley Gramacho da Silva \\ Computer Science Department \\ Federal University of Tocantins \\ Palmas/Tocantins - Brazil
}

\begin{abstract}
This article aimed to perform a literature review on analytical methods and the information technology solutions developed for the management of analytical methods applied in academic and laboratory environments. Searches were carried out in the computer program registration database of the Brazilian National Institute of Industrial Property (INPI) and national and international publications. The literature points out that there are few systems developed for the academic area. Therefore, there is a necessity for the development of new solutions that meets the needs of professors and students in the area of analytical chemistry, for the management of methods used and adapted in academic environments.
\end{abstract}

\section{General Terms}

Analytical methods, innovation, technology, method management, information technology solutions

\section{Keywords}

Analytical methods, innovation, technology, method management

\section{INTRODUCTION}

Analytical chemistry studies the elaboration and theory of chemical analysis methods, which make it possible to determine the qualitative and quantitative composition of substances, playing an important role in many areas of science: food, agricultural, environmental, pharmaceutical, medicine, among others [1]. The qualitative analysis deals with the methods for determining the nature of the constituents of a substance by revealing the identity of the elements and compounds in a sample, while quantitative analyzes consist of the methods for determining the proportion in which the constituents are present in a sample $[2,3]$.

In this context, there are several official analytical methodologies recommended by national and international control bodies to standardize and guarantee the quality and reliability of the analysis results. For a method to be officially recognized, it needs to be validated following the established parameters. According to the National Health Surveillance Agency - ANVISA, this validation process consists of demonstrating that the analytical method produces reliable results and is suitable for the purpose for which it is intended, in a documented manner and according to objective criteria [4].

Most international analytical methods are adopted and described by AOAC International, a leader in analytical excellence, where it promotes food security, food integrity and public health, bringing together members, organizations and experts dedicated to the development and validation of standards, globally recognized methods [5]. In Brazil, one of the bodies officially recognized for standardizing analytical methodologies is the Adolfo Lutz Institute, which describes protocols for analysis of water, food, among others [6].

In general, researchers use these analytical methods daily in research, technical reports, technological innovations, and practical classes. However, according to the raw material to be analyzed and the availability of infrastructure, some adaptations are common and necessary.

The analytical laboratories perform a series of functions, including control of the analytical methods used, in addition to the management of material and human resources involved in the process of quantitative and qualitative characterization of samples. In this context, Cecchi [7] highlights that, in general, analytical processes are used both for research of new analytical methodologies, as for the development of new products and quality control of existing products, generating a demand for efficient operational management and careful. For Skobelev et al. [8] it is essential, therefore, the development of information management systems for the successful implementation of these management activities.

Regarding the flow of information generated in analytical laboratories, Heinle et al. [9] draw attention to the large volume of steps, processes and resources that require care and precision, creating the need for innovative tools for method management, which go beyond the traditional control notebooks and spreadsheets. In this sense, innovation will promote improvement in the production environment, resulting in new products, services or processes or that comprise the aggregation of new functionalities or characteristics [10].

\section{ANALYTICAL METHODS}

The analytical methods refer to the way of carrying out the analysis and describe in detail the steps necessary to carry out each analytical test. Those may include the sample, preparation of reagents, use of apparatus, handling of formulas for calculations, and others. The analysis consists of sample collection, decomposition, separation, concentration, detection and measurement, treatment, and evaluation of analytical data. $[11,12]$.

In this context, Skoog [2] demonstrates the steps involved in quantitative analysis, which can be seen in Figure 1. 


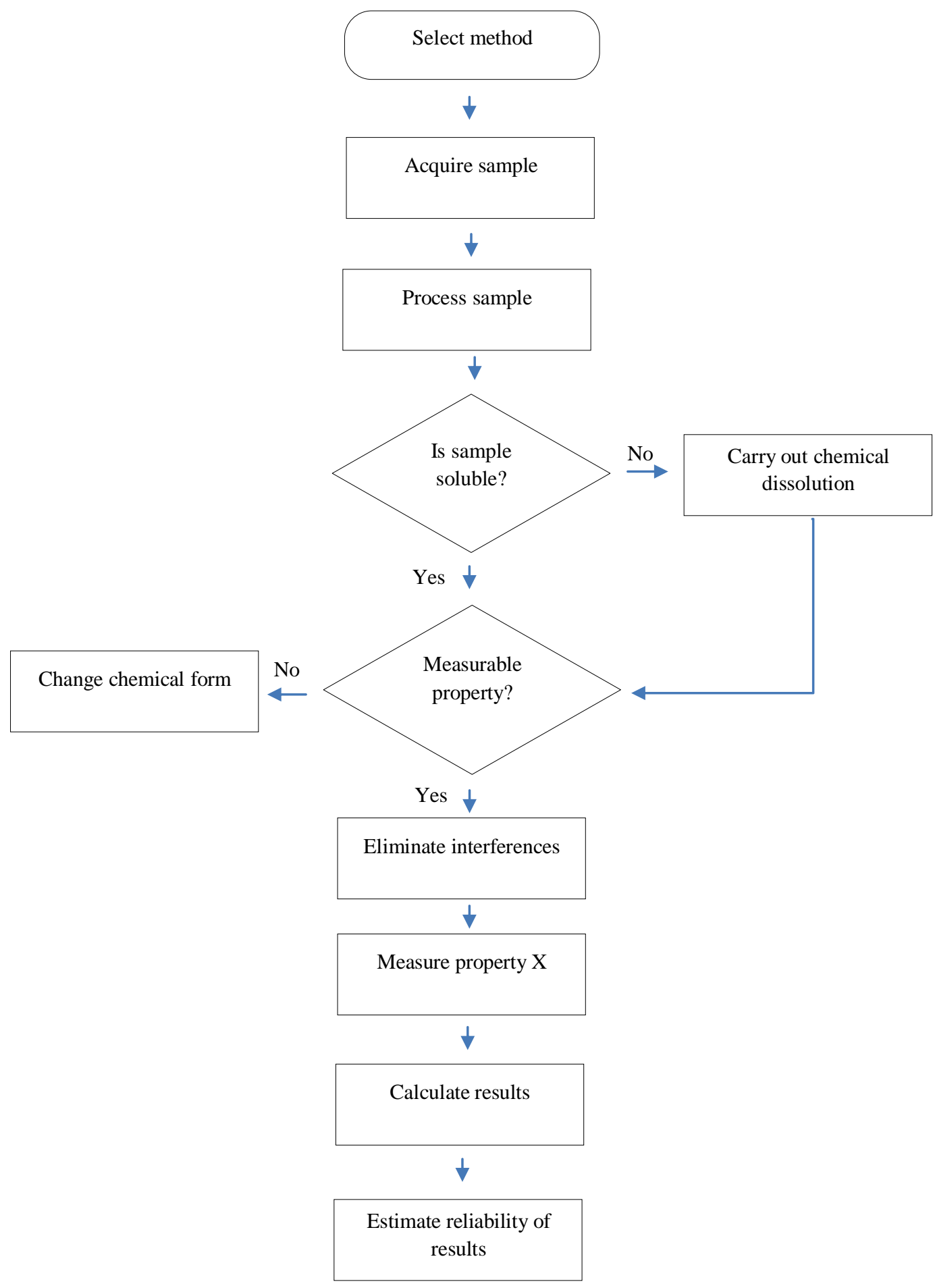

Figure 1:Flowchart of quantitative chemical analysis

To perform analytical methods, analytical techniques are also used, which are the procedures or instrumentation used for the qualitative or quantitative determination of the concentration of a compound. Examples of techniques are: titrations, spectroscopies, chromatography, and gravimetric analysis.

An example of the use of analytical technique occurs when the intention is to carry out the analysis of water, when the concentration of contaminants occurs, being necessary the use of analytical techniques of high sensitivity to detect and quantify them [13].
Given the importance of using analytical methods, official bodies such as the National Institute of Metrology, Quality and Technology (INMETRO) emphasize that it is of fundamental importance that laboratories have the means, criteria and objectives to prove and validate the test methods they perform lead to reliable results and adequate to the desired quality [14].

Method validation is one of the measures universally recognized as a necessary part of a comprehensive quality assurance system. In order to standardize these procedures, 
the International Union of Pure and Applied Chemistry IUPAC provides guidelines on the validation of analytical methods in the laboratory [15]. These guidelines provide minimum recommendations on procedures that should be employed to ensure proper validation of methods [16].

Analytical methods are standardized when they are developed by a standardization body. Non-standardized analytical methods are those developed by the laboratory itself or adapted from standardized and validated methods, that is, they are those developed or adapted to meet the specificities of the analysis $[17,18]$.

In the early 1990s, regulatory agencies in the United States, Japan, and Europe: FDA - Food and Drug Agency, MHLW Ministry of Health, Labor and Welfare, EMEA- European Medicine Agency respectively, organized the International Conference on Harmonization-ICH, which had as one of its goals the publication of guides containing the characteristics to be considered during the validation of the analytical procedures [19].

In Brazil, INMETRO and ANVISA are responsible for the publication of standards for the validation of analytical methods. The Adolfo Lutz Institute is the principal reference in the publication of analytical methods and performs hundreds of tested and reliable analytical methods available to laboratories and the scientific community, in general [20].

The Ministry of Agriculture, Livestock and Supply - MAPA also publishes publications on analytical methods related to fertilizers and correctives; control of milk and dairy products; and food of animal origin. Some of these publications are listed in Table 1 and cover guides and manuals containing widely recognized methods and validation procedures.

Table 1: Publications by Brazilian government agencies related to official methods and validation of analytical methods

\begin{tabular}{|l|l|}
\hline Government agency & \multicolumn{1}{c|}{ Publication } \\
\hline $\begin{array}{l}\text { Ministry of } \\
\text { Agriculture, } \\
\text { Livestock and Supply } \\
\text { - MAPA }\end{array}$ & $\begin{array}{l}\text { Manual of Official Analytical } \\
\text { Methods for Fertilizers and } \\
\text { Remedies }\end{array}$ \\
\hline Ministry of & Official Physical-Chemical \\
\hline
\end{tabular}

\begin{tabular}{|l|l|}
\hline $\begin{array}{l}\text { Agriculture, } \\
\text { Livestock and Supply } \\
\text { - MAPA }\end{array}$ & $\begin{array}{l}\text { Analytical Methods for } \\
\text { Control of Milk and Dairy } \\
\text { Products }\end{array}$ \\
\hline $\begin{array}{l}\text { Ministry of } \\
\text { Agriculture, } \\
\text { Livestock and Supply } \\
\text { - MAPA }\end{array}$ & $\begin{array}{l}\text { Official Analytical Methods for } \\
\text { Food Analysis of Animal Origin }\end{array}$ \\
\hline $\begin{array}{l}\text { Instituto Adolfo Lutz } \\
\text {-IAL }\end{array}$ & $\begin{array}{l}\text { Physico-chemical methods for } \\
\text { food analysis }\end{array}$ \\
\hline $\begin{array}{l}\text { National Health } \\
\text { Surveillance Agency } \\
\text { - ANVISA }\end{array}$ & $\begin{array}{l}\text { RDClidation of analytical methods } \\
\text { used in inputs harmaceuticals, } \\
\text { medicines and biological } \\
\text { products in all their production } \\
\text { phases }\end{array}$ \\
\hline $\begin{array}{l}\text { National Institute of } \\
\text { Metrology, Quality } \\
\text { and Technology - } \\
\text { INMETRO }\end{array}$ & $\begin{array}{l}\text { DOQ-CGCRE-008: Guidance } \\
\text { on validation of analytical } \\
\text { methods }\end{array}$ \\
\hline
\end{tabular}

There are several international associations and bodies that develop, validate and publish analytical methods, among them is the Association of Official Analytical Collaboration AOAC INTERNATIONAL, a world reference in the study of analytical methods. Many countries, including Brazil, reference and recommend the use of validated and adopted methods by the association. AOAC INTERNATIONAL brings together governments, industries, and academia to develop and validate analytical methods that guarantee the safety and integrity of food and other products that impact public health worldwide [5].

In addition, AOAC has the Official Methods of Analysis (OMA) program, which maintains the most comprehensive collection of chemical and microbiological methods available in the world, used in industry, regulatory agencies, research organizations, analysis laboratories, and academic institutions. Many countries and organizations contribute their expertise to the development of standards and method validation. [5].

Figure 2 presents an example of the format of a method published by AOAC 


\section{Guide to Method Format}

(Method shown is incomplete to allow space for description.)

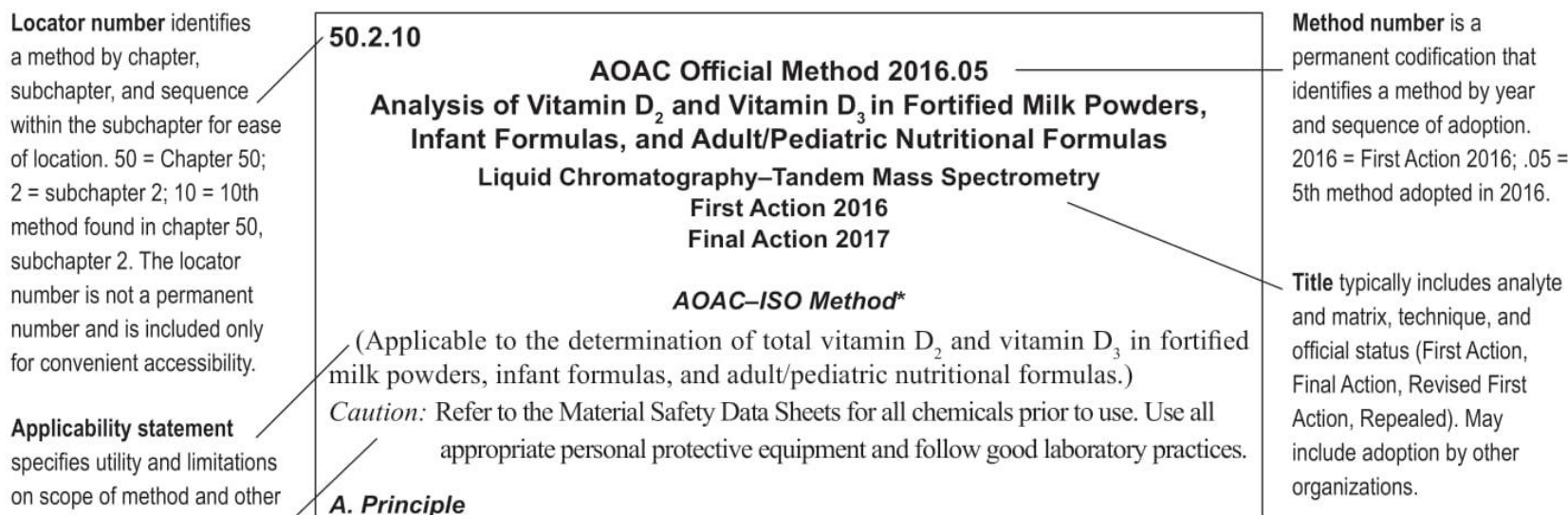

on scope of method and other pertinent information.

Cautionary statement specifies precautions and possible hazards in carrying out method, including safety information on equipment, techniques and practices, and safe handling of chemicals, acids, alkalies, microorganisms, and solvents.

Calculation symbols are defined and show correct units.

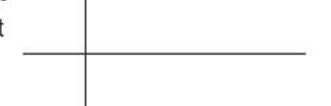

$$
\mathrm{SILD}_{2} \mathrm{SS}_{\mathrm{D} 2 \mathrm{concn}}=\frac{\operatorname{SILD}_{2} \mathrm{SS}_{\mathrm{abs}(\lambda \max )}}{\mathrm{E}_{1 \mathrm{~cm}}^{1 \%}} \times 10000
$$

where $\mathrm{SILD}_{2} \mathrm{SS}_{\mathrm{D} 2 \mathrm{conc}}=$ concentration of $d 6$-vitamin $\mathrm{D}_{2}$ in the stock standard $(\mu \mathrm{g} / \mathrm{mL}) ; \operatorname{SILD}_{2} \mathrm{SS}_{\text {abs }(\lambda \max )}=U \mathrm{UV}$ absorbance of the stock standard at $265 \mathrm{~nm}\left(\mathrm{~cm}^{-1}\right)$; $\mathrm{E}_{1 \mathrm{~cm}}^{1 \%}=$ extinction coefficient for vitamin $\mathrm{D}_{2}$ in ethanol $(461 \mathrm{dL} / \mathrm{g} \cdot \mathrm{cm})$; and 10000 $=$ concentration conversion factor $(\mathrm{g} / \mathrm{dL}$ to $\mu \mathrm{g} / \mathrm{mL})$.

References: J. AOAC Int. 99, 1321(2016) DOI: $10.5740 /$ jaoacint. 16-0160 (First Action)

\section{J. AOAC Int. 101, 256(2018)}

DOI: $10.5740 /$ jaoacint. 17-0149 (Final Action)

Method may include Chemical Abstracts Service (CAS) registry numbers, unique identifiers used to search a number of data-retrieval systems.
J. AOAC Int. 95, 292(2012) (AOAC SMPR 2011.004) DOI: $10.5740 /$ jaoac.int.11-0440

CAS-50-14-6 (ergocalciferol)

Revised: January 2019
References direct the user to published validation studies (single- and/or multilaboratory), subsequent revisions, and relevant SMPRs $®$. Other informative references may be included.

Revision date at the end of method signifies that the method received minor editorial revisions (that do not affect method procedures). 


\section{LIMITATIONS ON ACCESS TO ANALYTICAL METHODOLOGIES}

There is a wide variety of methodologies published in different databases, in scientific journals, in official documents from government agencies and international associations. A search on the SCOPUS platform using the terms TITLE-ABS-KEY ("analytical method") AND (LIMITTO (DOCTYPE, "ar")), resulted in more than 92 thousand publications between 1896 to 2021. Figure 2 shows the publications of the articles by area, where the amplitude of the areas associated with analytical chemistry is verified.

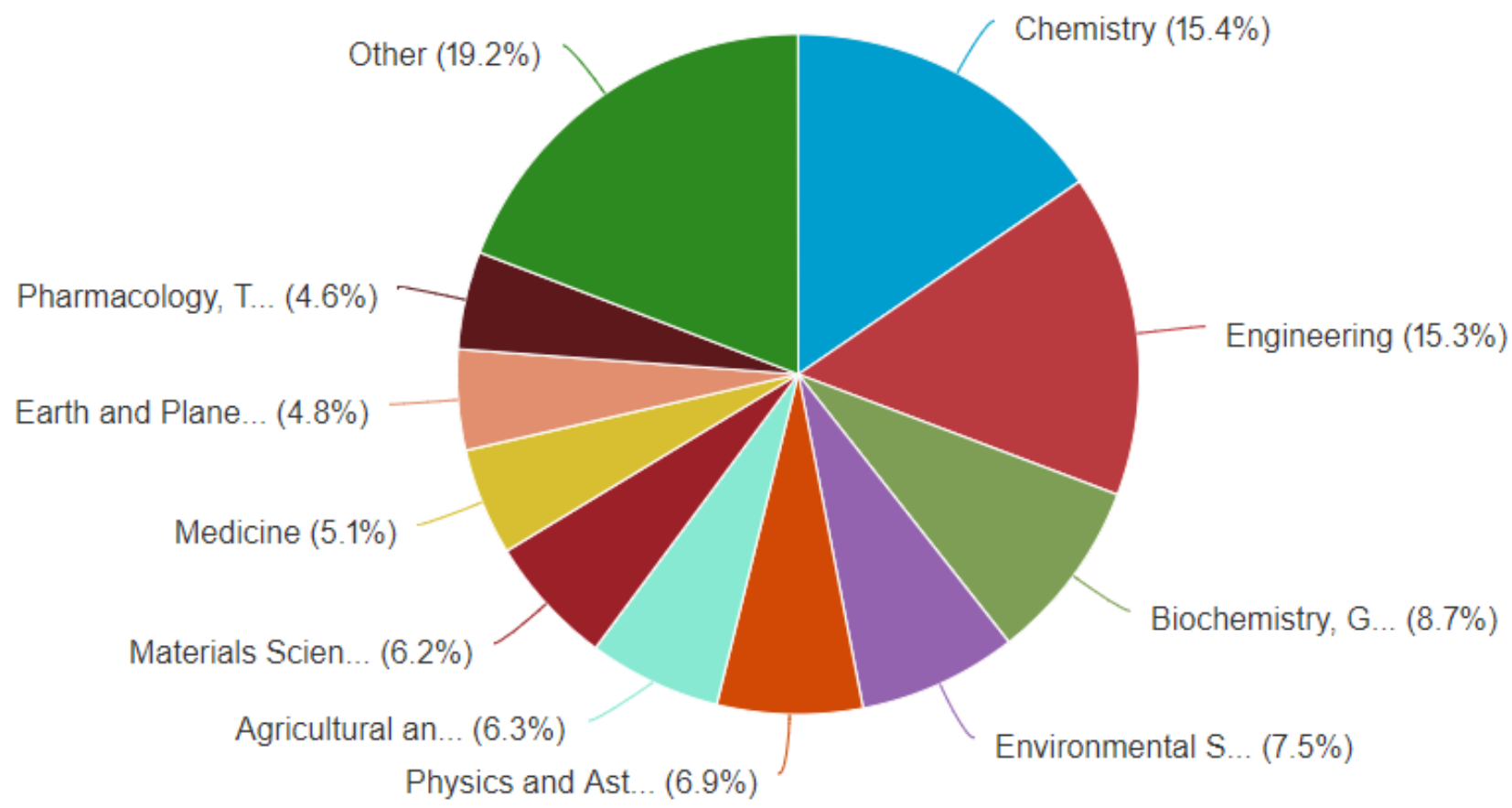

Figure 3: Documents by subject area

For a method to be recognized and standardized by a regulatory body, it is necessary for validation, carried out by an interlaboratory study, to assess the performance of the method. Such a validation study involves time and costs for the members participating in the study [21].

If an existing method is modified to meet specific requirements or an entirely new method is developed, the laboratory must ensure that the performance characteristics of the method meet the requirements for the intended analytical operations. For modified methods (standardized or not) or developed by the laboratory, there are a series of parameters to be evaluated to ensure the suitability of the method for the intended use [22].

In this sense, laboratory management systems usually have support characteristics, but without sharing information and adaptations, generating duplication of efforts and, consequently, increasing costs and spending time in the use of human and material resources for the application and development of methods.

\section{SYSTEMS APPLIED TO MANAGEMENT OF CHEMICAL ANALYSIS LABORATORIES}

A Laboratory Information Management System is a computer-based application software product used in the laboratory to manage standard analyzes and samples, test results, laboratory staff, and analytical equipment, as well as for the purpose of generating reports and other functions [23].
In this context, Mclelland [24] highlights how a laboratory information management system is perceived depending on the user's point of view:

- For an analyst, it is, in fact, the computer system that interfaces with its analyzer, calculates, stores, and prints results;

- For a laboratory manager, it is the system that allows you to track samples, identify your current status, audit your response times and provide better data on your customer base than he has already obtained from the best-organized paper records;

- For a management information systems analyst, however, the product can and should be a feeder system, transmitting resource management data to the corporate mainframe and;

- For an accountant, he can integrate laboratory costs into the customer's invoice.

Currently, management systems are mostly developed in the client-server architecture, in which the request processing and database are located on the server, while the system's graphical interface is present on the client. Figure 4 presents the client-server architecture.

It is possible to exemplify this architecture when performing a search on Google. When accessing the homepage, the graphical interface of the Google search system is loaded on the device and when a search for an expression is performed, this request is sent to a server, where it is processed and then the result is returned to the client. Figure 4 represents the 
schema of the client-server architecture.

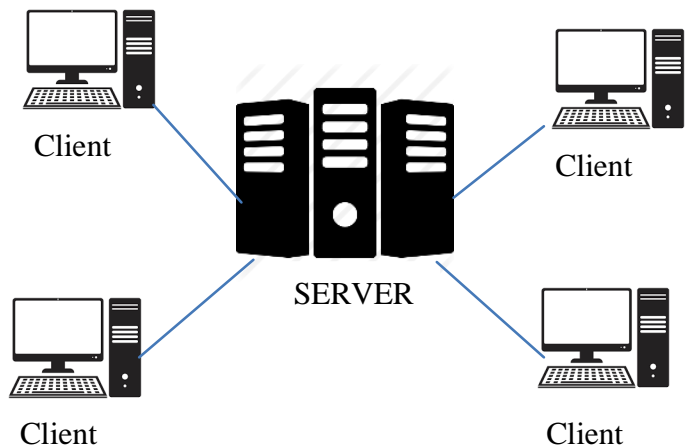

Figure 4:Client-server architecture

In a search carried out in the database of records of computer program records of the Brazilian National Institute of Industrial Property - INPI, using the search term, "Laboratório and quimica", and search criteria "any of the words", were found among 1993 to 2020, 52 computer program registration application processes. Among them are listed in Table 2 some records that may be related to management analytical methods.

Table 2:Computer program records at the Brazilian National Institute of Industrial Property (INPI)

\begin{tabular}{|c|c|l|}
\hline CODE & $\begin{array}{c}\text { YEAR } \\
\text { OF } \\
\text { ORDER }\end{array}$ & \multicolumn{1}{|c|}{ TITLE } \\
\hline $\begin{array}{c}\text { BR 51 2018 } \\
0520375\end{array}$ & 2018 & $\begin{array}{l}\text { CFQ- Physicochemical } \\
\text { Calculator }\end{array}$ \\
\hline $\begin{array}{c}\text { BR 51 2017 } \\
0010048\end{array}$ & 2017 & $\begin{array}{l}\text { Intelligent system for control } \\
\text { of reagents used in laboratory } \\
\text { practices of the course in } \\
\text { degree in chemistry }\end{array}$ \\
\hline $\begin{array}{c}\text { BR 51 2016 } \\
0013460\end{array}$ & 2016 & $\begin{array}{l}\text { ILABORATORY: Virtual } \\
\text { chemistry laboratory }\end{array}$ \\
\hline $\begin{array}{c}\text { BR 51 2015 } \\
0002228\end{array}$ & 2015 & $\begin{array}{l}\text { LABWIN-Chemical } \\
\text { metrology software }\end{array}$ \\
\hline $\begin{array}{c}\text { BR 51 2019 } \\
0005708\end{array}$ & 2019 & $\begin{array}{l}\text { BIT LABS - Application for } \\
\text { management of bromatology } \\
\text { laboratory }\end{array}$ \\
\hline $05277-5$ & 2010 & $\begin{array}{l}\text { SILAS-Computerized } \\
\text { System for Analysis } \\
\text { Laboratories }\end{array}$ \\
\hline
\end{tabular}

ILaboratory is an iPhone application developed at the Federal University of $\mathrm{ABC}$ that acts as a chemistry lab simulator limited to reproducing flame test and wet test experiments [25].

The LABWIN System is proprietary software that proposes to manage data from laboratories and industrial processes; management of proficiency testing programs (interlaboratory), validation of methods, calculation of uncertainties, control of quality documents, and other functions [26]. However, the system is focused on industrial environments and is not ideal for academic environments.

The Computerized System for Analysis Laboratories - SILAS is also proprietary software developed for analysis: soil chemistry, soil physics, leaf or plant tissue, seeds; limestone, mineral salt, and fertilizers; nutrients (amino acids), and others [27]. In this context, it is a specific software and it has functionalities aimed at analysis, not specifically for the management of analytical methods.

\section{CONCLUSION}

In general, it is observed that the software present in the market aim to meet a specific demand, with limitations of functionalities for the operationalization and management of academic analytical laboratories, thus launching a demand for an analytical methods management system that serve both the academic and industrial audiences.

The research in the literature showed the importance of developing, in future works, a management solution for analytical methods that can support students, and professors, in practical classes, laboratory routines. Besides, it allows to optimize the dynamics of scientific experimentation in the laboratory and maximize the sharing of adaptations made within the scope of practice.

\section{REFERENCES}

[1] Forte, C. M. S.; Melo Pacheco, L. C.; Queiroz, Z. F. 2019. Química Analítica I. 2a . ed. Fortaleza - Ceará. Ed UECE.

[2] Skoog, DA; West, DM; Holler, FJ. 1992. Fundamentals of Analytical Chemistry. [27]

[3] Hall, T.; Treadwell, F. P. 1921.Analytical Chemistry: Qualitative Analysis. New York: John Wiley \& Sons, Inc, v. 1.

[4] ANVISA. 2017. Resolução da diretoria Colegiada RDC $\mathrm{n}^{\circ}$ 166, de 24 de julho de 2017.

[5] AOAC. 2020. About AOAC INTERNATIONAL. AOAC.

[6] Zenebon, O.; Pascuet, N. S.; Tiglea, P. 2008. Métodos físico-químicos para análise de alimentos.4 ed. digital. São Paulo: Instituto Adolfo Lutz. 1020p.

[7] Cecchi, Heloísa Máscia. 2003.Fundamentos teóricos e práticos em análise de alimentos. Ed. UNICAMP.

[8] Skobelev, D. O. et al. 2011.Laboratory information management systems in the work of the analytic laboratory. Measurement Techniques, v. 53, n. 10, p. 1182-1189.

[9] Heinle, Cassie Elizabeth et al. 2017. MetaLIMS, a simple open-source laboratory information management system for small metagenomic labs. GigaScience, v. 6, n. 6, p. gix025.

[10] BRASIL. 2016. Presidência da República Casa Civil.Lei $\mathrm{N}^{\mathrm{o}} 13.243$, de 11 de janeiro de 2016.

[11] FDA. 1995.Text on Validation of Analytical Procedures.

[12] Arikawa, Yoshiko. 2002.Basic education in analytical chemistry. In: Analytical Sciences/Supplements Proceedings of IUPAC International Congress on Analytical Sciences 2001 (ICAS 2001). The Japan Society for Analytical Chemistry. p. i571-i573.

[13] Santos, L. M. G.; Gonçalves, J. M.; Couto, S. 2008. Determinação simultânea de $\mathrm{As}, \mathrm{Cd}$ e $\mathrm{Pb}$ em amostras de água purificada para hemodiálise por espectrometria de absorção atômica com forno de grafite, após otimização multivariada baseada no uso de planejamento experimental. Química Nova, São Paulo, v. 31 no.5. 
[14] INMETRO. 2020. Coordenação Geral de Acreditação. DOQ-CGCRE-008: orientação sobre validação de métodos analíticos. Rio de Janeiro. 30p. Revisão nº 09.

[15] IUPAC. 2020. What we do. IUPAC.

[16] Thompson, M., S.L.R. Ellison, and R. Wood. 2002. Harmonized guidelines for single-laboratory validation of methods of analysis - (IUPAC technical report).Pure and Applied Chemistry, 74(5): p. 835-855.

[17] INMETRO. 2007. Coordenação Geral de Acreditação. DOQ-CGCRE-008: orientação sobre validação de métodos analíticos. Rio de Janeiro. 25p. Revisão $n^{\circ} 02$

[18] INMETRO. 2013. Coordenação Geral de Acreditação. DOQ-CGCRE-020: Definições de termos utilizados nos documentos relacionados à acreditação de laboratórios, produtores de materiais de referência e provedores de ensaios de proficiência. Rio de Janeiro. 12p. Revisão $\mathrm{n}^{\circ}$ 06.

[19] ICH. 1995.International Conference on Harmonisation. ICH Topic Q 2 (R1) Validation of Analytical Procedures: Text and Methodology.

[20] IAL. 2020. Instituto Adolfo Lutz. Apresentação

[21] Mano, Junichi; Takabatake, Reona; Kitta, Kazumi. 2020.
Development and Standardization of Analytical Methods for Increasing Varieties of Genetically Modified Crops. Japan Agricultural Research Quarterly: JARQ, v. 54, n. 2, p. 113-119.

[22] INMETRO. 2020. Coordenação Geral de Acreditação. DOQ-CGCRE-008: orientação sobre validação de métodos analíticos. Rio de Janeiro. 30p. Revisão n 09.

[23] Skobelev, D. O. et al. 2011.Laboratory information management systems in the work of the analytic laboratory. Measurement Techniques, v. 53, n. 10, p. 1182-1189.

[24] Mclelland, A. 1998. "What is a LIMS - a laboratory toy, or a critical IT component?" (PDF). Royal Society of Chemistry. p. 1.

[25] Bertolini, C. T.; Braga, J. C.; Pimentel, E.; Ramos, S. 2013. Laboratório Virtual interativo para reprodução de experimentos de química através de dispositivos móveis. Brazilian Symposium on Computers in Education (Simpósio Brasileiro de Informática na Educação-SBIE). p. 285.

[26] Labwin. 2020. Laboratory Software.Historioco.

[27] Silas. 2020.Sistema Informatizado para Laboratórios de Análise.Megatecnologia-si. 